tributed by Dr. Hjort and Dr. Appellöf in chapters vii. and viii., the former writing on the fishes, the latter on the invertebrates. It is a task of no little difficulty to treat such extensive subjects in a concise and yet comprehensive way. With the help of a large series of figures illustrating the numerous species mentioned, both authors have succeeded well, and it is to be hoped that their efforts may result in reviving popular as well as general scientific interest in these branches of marine biology, which, fascinating as they are, have rather tended to become of late years entirely relegated to specialists on particular groups.

Following these, chapter ix., on pelagic animal life, by Dr. Hjort, contains perhaps the largest proportion of original matter to be found in the book. This is due to the fact that the collecting gear chiefly used by the expedition consisted of townets and large pelagic nets of various patterns, all of them of very much greater fishing capacity than the nets which have previously

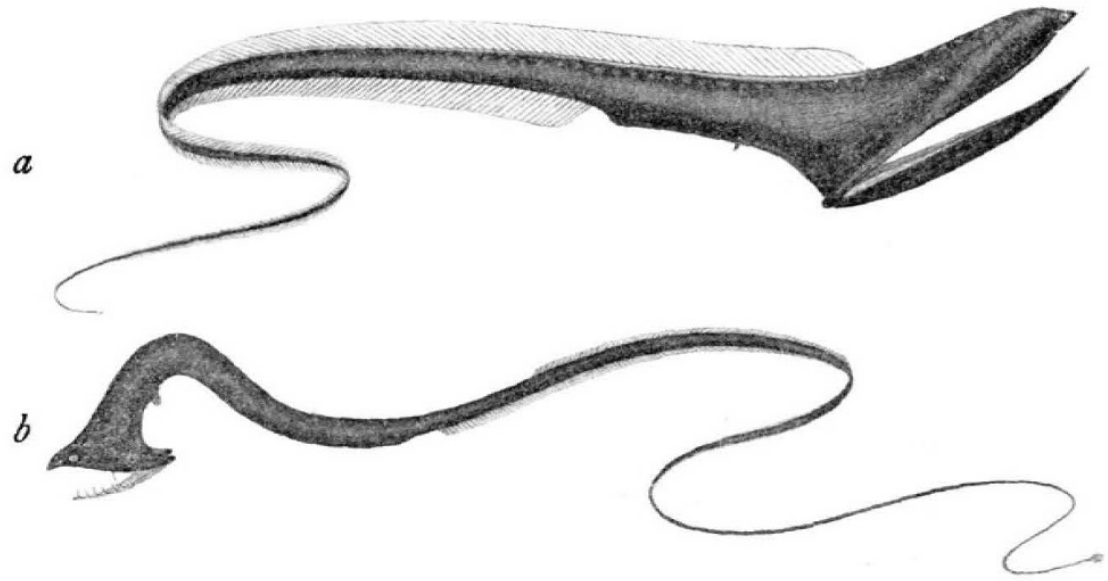

Fig. 4.-Two Gastrostomidx. a. Gastrostomus bairdii, Gill and Ryder. Nat. size, $47 \mathrm{~cm}$. b. New Genus. Nat. size, $20 \mathrm{~cm}$. From "The Depths of the Ocean."

been used in ocean work. From the nature of the results already reached-and the material has as yet been only partially worked out-it seems clear, as Dr. Hjort maintains, that the qualitative results obtained by the use of these large nets towed for long periods give a more correct and comprehensive picture of the free-swimming life of the Atlantic than was obtained with the relatively small nets used by the German plankton expedition, the material from which Prof. Hensen and his helpers have attempted to work out quantitatively at the cost of such vast labour.

The final chapter, entitled "General Biology," is also written by Dr. Hjort. It deals with innumerable problems of scientific importance in a most suggestive and stimulating way, and maintains the high standard of the whole book to the end. Among the numerous questions dealt with are the colours of marine animals and their relation to the conditions in which these animals live, phosphorescence and luminous organs, the eyes of deep-sea fishes and the meaning of the No. 2243 , VOL. 90] great variations in their size in different species, the factors which influence the floating of pelagic organisms, and the organs which are special adaptations for floating.

One other subject in this final chapter must not be passed without notice-namely, the valuable contribution made by the Michael Sars expedition to the wonderful story of the lifehistory of the fresh-water eel. The expedition secured numerous eel larvæ of stages much younger than any previously found, and from the distribution of these larvæ the conclusion seems justified that the eel spawns south of the latitude of the Azores, and the larvæ are later carried into the northern North Atlantic and towards the coasts of northern Europe by the Gulf Stream.

Nothing could be more calculated than this book to awaken fresh interest in the importance of the thorough and complete investigation of the problems of the great oceans. A knowledge of the changes which take place from season to season and from year to year in the Atlantic would be of incalculable value to every country in Europe, for there can now be scarcely a doubt that it is upon these changes that the variations in the yield of the harvests both of the land and of the sea are mainly dependent. These changes can never be ascertained by single cruises such as that of the Michael Sars, brilliantly though that cruise was carried out. What we now want is systematic and sustained researches extending over a period of years. Great Britain did the pioneer work in connection with ocean research, and the time is fully ripe when a comprehensive scheme of investigation in the Atlantic should be organised in this country. The present notice can have no better conclusion than the expression of the hope that Sir John Murray will use his great experience and commanding position in trying to ensure that the British Government should make the necessary provision for such an investigation.

E. J. Allen.

\section{THE SWISS SOCIETY OF NATURAL SCIENCES.}

THE Société Helvétique des Sciences naturelles, 1 which, in Switzerland, takes the place of a scientific academy, and is the centre of all concerted action in the scientific life of that country, held its annual reunion at Altdorf, in the canton of Uri, on September 8-10.

The first day was devoted to a general assembly, at which various matters were discussed, and some 
general addresses also delivered. Profs. Kovalski, Wiechert, and Weiss reviewed recent work on radiations, atmospheric electricity, and the rôle of magnetic phenomena in the study of molecular and atomic conceptions. The second day was devoted to meetings of sections, at which a great number of communications were presented on mathematics, physics, chemistry, geology and mineralogy, botany, and zoology. Finally, on the concluding day another general assembly was held, again devoted to administrative matters and general addresses, among which may be specially mentioned that by Prof. Chodat, on vegetable pigment, and that by Dr. Paul Sarasin, on the Swiss National Park.

The Société Helvétique des Sciences naturelles, founded at Geneva in 1815 , has been the moving spirit in many important scientific undertakings in Switzerland. It has successfully created, or, at least, been the means of creating, the fine topographical map of Switzerland, the geological, geodetical, and meteorological services, the investigations of earthquakes, glaciers, rivers, lakes and marshes. The various branches of work are directed by special commissions or committees, selected from the Society's ranks, which send in reports annually; they receive grants from the Swiss Government totalling annually about 80,000 francs $(3200 l)$. As each branch expands in course of time, and grows in importance, it is usually taken over by the Swiss Government and given an independent organisation. It is in this way that the Swiss Federal Services of Topography and Meteorology have originated, and the seismological service started and organised by the Society is now passing into the hands of the Federal Government in like fashion. By way of counterpoise, the creation of a new commission was decided at the Altdorf meeting, to be charged with organising studies and regular observations of atmospheric electricity.

But of all the recent activities of the Society, the most interesting for its importance and bearing is the work of the Commission for the Protection of Natural Sites, organised in 1906, which has culminated in the creation of a magnificent national park, situated in the lower valley of the Inn (Grisons), one of the wildest parts of the Swiss Alps. In accordance with contracts made with the commune of Zernez and various neighbouring communes, an uninterrupted stretch of territory of about Ioo square kilometres area, which it is hoped soon to extend to 200 square kilometres, will be almost completely withdrawn from the interference of man. The flora and fauna, which are here relatively very rich-the region is still frequented by chamois, and a few bears are still met with-will be able to develop freely in accordance with natural laws of evolution. The only exception will be a few roads or paths to give access to the reservation, and some blockhouses constructed for the purposes of repressing poaching, enforcing the prohibition of hunting, and organising a service of regular observations. It will thus be possible to study the formation of a natural "biocénose" on a somewhat magnificent scale-a true "biological refuge" of a most interesting kind.

Part of the territory leased by the Society for the National Park of the Grisons has been taken for twenty-five years, the rest for ninety-nine years. The costs of rent, surveillance, and observations will be defrayed out of funds furnished by a popular league, the "Ligue suisse pour la protection de la nature" (founded under the auspices of the Société Helvétique des Sciences naturelles), the ordinary members of which pay an annual contribution of at least a franc, and the life members a lump sum of at least twenty francs. The Federal Government also has announced its intention of applying to the Chambers for regular annual grants.

The above details, taken from the bulky report of the Central Committee, and from the interesting address of Dr. Paul Sarasin, President of the Commission for the Protection of Natural Sites, prove that Swiss naturalists have made a great achievement. The "Territoire Réservé" of the Grisons is not only the most important in Europe, on account of its extent, but in some respects excels the celebrated American Reservations, which are only partially reserved, and do not form one unbroken block.

\section{THE UNIVERSITY OF BRISTOL.}

Installation of LoRd Haldane as Chancellor. THE installation of Lord Haldane as Chancellor 1 of the University of Bristol on Thursday last, October $\mathrm{I}_{7}$, in succession to the late $\mathrm{Mr}$. H. O. Wills, was made the occasion of a brilliant and memorable ceremony. Bristol, the ancient city of the west, is the youngest of the new universities; and it is peculiarly fortunate in having secured for its chancellor one who represents the modern spirit of organisation and progress. In presenting the deed to the chancellor, Mr. Lewis Fry expressed the profound satisfaction of the University that he had been able to accept the unanimous invitation to become its head. Lord Haldane, in the course of reply, remarked that he had spent a considerable part of his life and such energy as he possessed in endeavouring to forward the cause of the new civic university, and he hoped to be permitted to mould and fashion the operations of this great conception still further in the future.

In honour of the occasion, a large number of honorary degrees were conferred upon men and women distinguished in letters, art, science and public services. Lord Haldane himself received the patent of the honorary degree of LL.D., and among the other recipients of degrees were the following, who were presented in the order given.

M.Sc. (Engineering).-John Munro, professor of mechanical and mining engineering in the University.

M.D.S.-W. R. Ackland, lecturer in dental surgery in the University.

M.Ch. -N. C. Dobson, emeritus professor of surgery in the late University College, Bristol; J. P.

$$
\text { NO. 2243, VOL. 90] }
$$

